\title{
Dense Phase Carbon Dioxide: A Novel Non-Thermal Technique for Inactivation of Micro-Organisms in Food
}

Asutosh Mohapatra*

Centre for Rural Development and Technology, Indian Institute of Technology, India

*Corresponding author: Asutosh Mohapatra, Centre for Rural Development and Technology, Indian Institute of Technology, Delhi, India

Submission: 眥 April 28,2018; Published: 眥July 05, 2018

\begin{abstract}
Dense phase $\mathrm{CO}_{2}$ (DPCD) is a non-thermal technology that can inactivate certain micro-organisms and enzymes at temperatures low enough to avoid the thermal effects of traditional pasteurization. This technology has been investigated over the past 50 years, particularly in the past 2 decades, and its effects on vegetative cells and spores of various microorganisms including pathogens, spoilage bacteria, yeasts, and molds, and various enzymes of importance to foods have been demonstrated. Many liquid foods retained fresh-like sensory, nutritional, and physical properties after DPCD treatment along with some solid foods. This paper is a review of mechanisms of microbial reduction, enzyme and spore inactivation, DPCD treatment systems and examples of applications with effects on quality attributes.
\end{abstract}

Keywords: Dense phase $\mathrm{CO}_{2}$; Non-thermal pasteurization; Microbial inactivation; Enzyme inactivation;Quality

\section{Introduction}

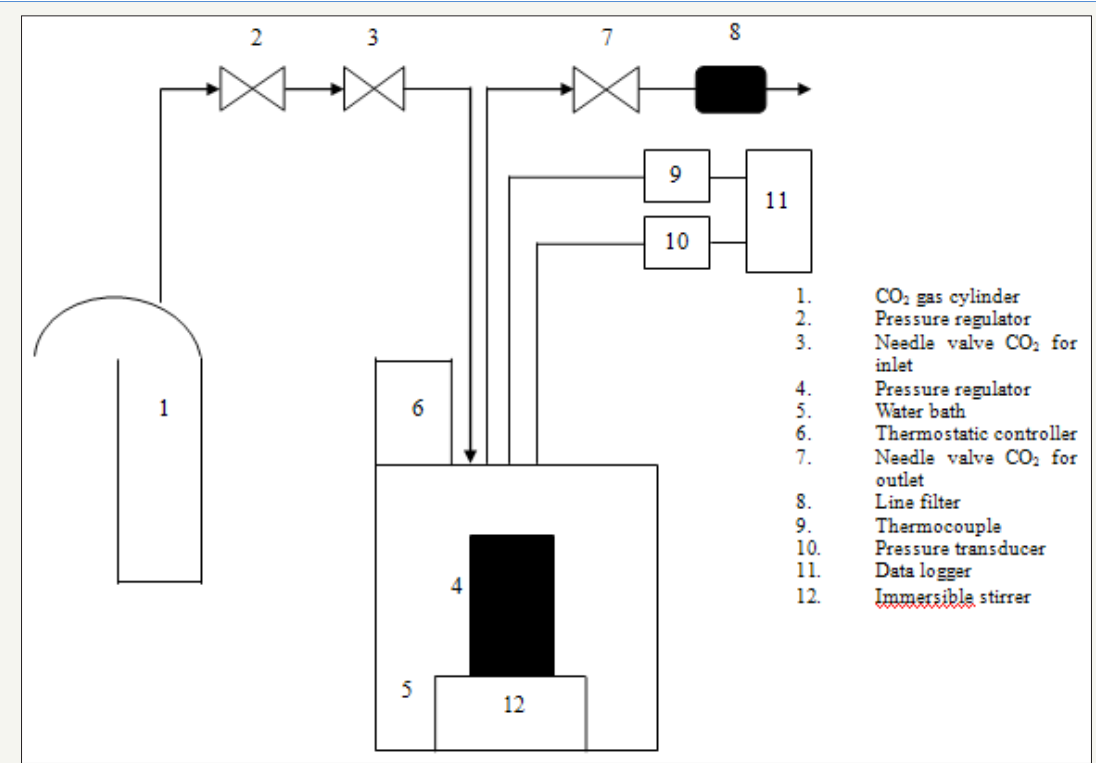

Figure 1: Block diagram of a batch type dense phase carbon dioxide (DPCD) system.

The need for a food preservation method that is safe, inexpensive, and that preserves heat-sensitive compounds resulted in the use of pressurized carbon dioxide $\left(\mathrm{CO}_{2}\right)$ as a food preservation method. $\mathrm{CO}_{2}$ is used because of its safety, low cost, and high purity. Dense-phase carbon dioxide (DPCD) treatment has attracted great interest in the non-thermal treatment of liquid foods or liquid model solutions. DPCD has been shown to inactivate microorganisms as well as conventional heat pasteurization without the loss of nutrients or quality changes that may occur due to thermal effects. In the DPCD process, food is contacted with 
pressurized sub- or supercritical $\mathrm{CO}_{2}$ for a period in a batch, semibatch or continuous manner. The $\mathrm{CO}_{2}$ pressures can range from 7.0 to $40.0 \mathrm{MPa}$. These levels are much lower than those of ultra high-pressure processes. Process temperatures can range from 20 to $60^{\circ} \mathrm{C}$ whereas treatment times can be ranged from about 3 to $9 \mathrm{~min}$ for continuous, or from 120 to $140 \mathrm{~min}$ for semi-continuous or batch DPCD processes. A block diagram of batch type DPCD system is given in (Figure 1).

\section{Inactivation of Micro-Organisms by DPCD}

The mechanism of inactivation of micro-organisms by DPCD is a complex phenomenon. Several authors have given many concepts of microbial inactivation through DPCD which are summarized below [1-6].

\section{pH lowering effect}

It has been found that $\mathrm{CO}_{2}$ can lower the $\mathrm{pH}$ of food matrix when dissolved in the aqueous part of food by forming carbonic acid, which further dissociates to give bicarbonate, carbonate and $\mathrm{H}^{+}$ions lowering extracellular $\mathrm{pH}$.

$$
\begin{aligned}
& \mathrm{CO}_{2}+\mathrm{H}_{2} \mathrm{O} \leftrightarrow \mathrm{H}_{2} \mathrm{CO}_{3} \\
& \mathrm{H}_{2} \mathrm{CO}_{3} \leftrightarrow \mathrm{H}^{+}+\mathrm{HCO}_{3}{ }^{-} \\
& \mathrm{HCO}_{3}{ }^{-} \leftrightarrow \mathrm{H}^{+}+\mathrm{CO}_{3}{ }^{-2}
\end{aligned}
$$

A good correlation is obtained between water and liquid foods under DPCD by predicting the $\mathrm{pH}$ and comparing with measured $\mathrm{pH}$ [7]. Lowering of $\mathrm{pH}$ is reduced by dissolved acids and salts in DPCD. The internal $\mathrm{pH}$ of microbial cells is responsible for greater part of destruction of micro-organisms. With abundancy in the environment, $\mathrm{CO}_{2}$ penetrates through the cell membrane consisting of phospholipid layers and lowers internal $\mathrm{pH}$ by exceeding the cell's buffering capacity. Cell always try to maintain a $\mathrm{pH}$ gradient between the internal and external environment by pumping $\mathrm{H}^{+}$ions out of the cell. But, the permeation of excess $\mathrm{CO}_{2}$ into cells causes in reduction of internal $\mathrm{pH}$ which inactivates the micro-organisms by inhibiting essential metabolic systems including enzymes [8].

\section{Inhibitory effect of molecular $\mathrm{CO}_{2}$ and bicarbonate ion}

Bacterial enzymes may be inhibited by $\mathrm{CO}_{2}$. At low $\mathrm{pH}$, proteinbound arginine may interact with $\mathrm{CO}_{2}$ to form a bicarbonate complex, inactivating the enzyme $[9,10]$. Other researches show that decarboxylases are inhibited by excess $\mathrm{CO}_{2}$, breaking the metabolic chain [11]. A complete inactivation of alkaline protease and lipase is observed at $35^{\circ} \mathrm{C}, 15 \mathrm{MPa}$ using a micro-bubble system. Another proposed mechanism is precipitation of intracellular carbonate $\mathrm{Ca}^{+2}, \mathrm{Mg}^{+2}$ from bicarbonate [12]. Certain types of $\mathrm{Ca}$ and
Mg sensitive proteins can be precipitated by carbonate resulting a lethal change to the biological system.

\section{Modification of cell membrane and extraction of cellular components}

Another mechanism suggested by the researchers is based on the lipo- and hydrophilicity and solvent characteristics of $\mathrm{CO}_{2}$. Research shows that extraction of intracellular substances such as phospholipids can be a possible mechanism of microbial inactivation [13]. Another proposed mechanism is that molecular $\mathrm{CO}_{2}$ diffuses into cell membrane and accumulates there because the inner layer is hydrophilic. Accumulated $\mathrm{CO}_{2}$ increases fluidity of the membrane due to the order loss of the lipid chains, also called the 'anesthesia effect', and this causes an increase in permeability [14]. Extraction of lipids or other vital components of cells or membranes causes inactivation. Cells treated with DPCD $\left(7 \mathrm{MPa}, 30{ }^{\circ} \mathrm{C}, 10 \mathrm{~min}\right)$ has irreversible cellular damage including loss of salt tolerance, leakage of UV-absorbing substances, release of intracellular ions, and impaired proton permeability [15].

\section{Disordering of the intracellular electrolyte balance}

Lethal damage to the biological system of the cells may also be produced when the applied $\mathrm{CO}_{2}$ pressure accumulates in the cytoplasmic interior of the bacterial cells. This may convert $\mathrm{HCO}^{-3}$ to $\mathrm{CO}_{3}^{-2}$, which can precipitate intracellular inorganic electrolytes (such as $\mathrm{Ca}^{+2}, \mathrm{Mg}^{+2}$ and similar ions) from cells and cell membranes. Since these inorganic electrolytes aid in maintaining the osmotic relationships between cells and their surrounding media, this can have deleterious effects on the volume of cells. Microbial inactivation achieved by DPCD ranges from 2 to 12 logs, using pressures below $50 \mathrm{MPa}$, and temperatures between $5^{\circ} \mathrm{C}$ and $60{ }^{\circ} \mathrm{C}$, mostly in the $25{ }^{\circ} \mathrm{C}$ to $35{ }^{\circ} \mathrm{C}$ range. Treatment time is significantly different; depending on the system used and can be as long as $6 \mathrm{~h}$ with batch system and as low as $2.5 \mathrm{~min}$ with continuous or semicontinuous system.

\section{Inactivation of Spores and Enzymes}

Spores are highly resistant forms of bacteria to the physical treatments such as heat, drying, radiation, and chemical agents [16]. A limited number of studies in the literature investigating inactivation of spores by DPCD show that the inactivation achieved, changes with treatment conditions, treatment systems, and the type of organism. Studies suggest that processing temperature has a significant role in inactivation of spores by DPCD. Several researchers observe that a temperature threshold should be exceeded to achieve a killing effect on bacterial or fungal spores

\begin{tabular}{|c|c|c|c|c|c|c|}
\hline \multicolumn{7}{|c|}{ Treatment in Batch Type DPCD System } \\
\hline Solution & Micro-organism & Pressure (MPa) & Time(min) & Temperature $\left({ }^{\circ} \mathrm{C}\right)$ & Log reduction & Reference \\
\hline \multirow{4}{*}{ Physiological saline } & Saccharomyces cerevisiae & 20 & 120 & 35 & $7.5(\mathrm{C})$ & \multirow{4}{*}{$\begin{array}{c}\text { Kamihir et al. } \\
\text { [19] }\end{array}$} \\
\hline & Escherichia coli & 20 & 120 & 35 & $6.5(\mathrm{C})$ & \\
\hline & Staphylococcus aureus & 20 & 120 & 35 & $5(\mathrm{C})$ & \\
\hline & Aspergillus niger & 20 & 120 & 35 & $5(\mathrm{C})$ & \\
\hline
\end{tabular}
[17-28]. This temperature can be different for different spores.

Table 1: Summary of the studies on inactivation of various microorganisms/ spores/ enzymes by dense $\mathrm{phase}^{\mathrm{CO}} \mathrm{O}_{2}$ (DPCD). 


\begin{tabular}{|c|c|c|c|c|c|c|}
\hline Herbs & Total bacteria count & 5.52 & 120 & 45 & 5-8 (C) & Haas et al. [20] \\
\hline Apple juice & Total bacteria count & 5.52 & 30 & 45 & $>3(\mathrm{C})$ & Ballestra et al. \\
\hline Orange juice & Total bacteria count & 5.52 & 30 & 55 & $4(\mathrm{C})$ & Erkmen [21] \\
\hline \multirow{3}{*}{ Nutrient broth } & E. coli & 6.21 & 120 & Room temp. & 2 & \multirow{3}{*}{$\begin{array}{c}\text { Shimoda et al. } \\
\text { [22] }\end{array}$} \\
\hline & S. aureus & 6.21 & 120 & Room temp. & 2 & \\
\hline & Salmonella seftenberg & 6.21 & 120 & Room temp. & 2 & \\
\hline Distilled water & Listeria monocytogenes & 6.18 & 120 & 35 & $9(C)$ & Wei et al. [16] \\
\hline Egg yolk & Salmonella thyphimirium & 13.7 & 120 & 35 & $>8$ & Erkmen [21] \\
\hline Orange juice & Total plate count (TPC) & 33 & 60 & 35 & 2 & $\begin{array}{c}\text { Arreola et al. } \\
{[23]}\end{array}$ \\
\hline Growth medium & S. cerevisiae & 6.9 & 15 & 35 & $7(C)$ & Lin et al. \\
\hline Growth medium & Leuconostocdextranicum & $6.9-20.7$ & $15-20$ & 35 & $>8$ & Lin et al \\
\hline Sterile water & S. cerevisiae & 4 & $>180$ & 40 & $8(C)$ & $\begin{array}{c}\text { Nakamura et al. } \\
{[24]}\end{array}$ \\
\hline \multirow{2}{*}{ Physiological saline } & S. cerevisiae & 25 & 30 & 35 & $6(C)$ & \multirow{2}{*}{ Ballestra et al. } \\
\hline & E. coli & 5 & 20 & 35 & $6(C)$ & \\
\hline Sterile water & S. cerevisiae & 15 & 60 & 40 & 8 & Kumagai et al. \\
\hline MRS broth & Lactic acid bacteria & 6.9 & 200 & 30 & 5 & Hong et al. [25] \\
\hline \multirow{9}{*}{ TSB w/ polymers } & Bacillus cereus & 20.5 & 240 & 60 & $8(C)$ & \multirow{9}{*}{ Dillow et al. } \\
\hline & Listeria innocua & 20.5 & 36 & 34 & $9(\mathrm{C})$ & \\
\hline & S. aureus & 20.5 & 240 & 40 & $9(C)$ & \\
\hline & Salmonella salford & 20.5 & 240 & 40 & $9(C)$ & \\
\hline & Pseudomonas aeruginosa & 20.5 & 240 & 40 & $8(C)$ & \\
\hline & \multicolumn{5}{|l|}{ E. coli } & \\
\hline & Proteus vulgaris & 20.5 & 30 & 34 & $8(C)$ & \\
\hline & Legionella dunnifi & 20.5 & 36 & 34 & $8(C)$ & \\
\hline & & 20.5 & 90 & 40 & $4(\mathrm{C})$ & \\
\hline Growth medium & Lactobacillus plantarum & 13.8 & 30 & 30 & $>6(C)$ & Hong et al. [25] \\
\hline PS with broth & L. monocytogenes & 6 & 75 & 35 & $6.98(\mathrm{C})$ & Erkmen [21] \\
\hline PS & Enterococcus faecalis & 6.05 & 18 & 35 & $8(C)$ & Erkmen [21] \\
\hline Fruit juice milk & E. faecalis & 6.05 & $180-360$ & 45 & $5(C)$ & Erkmen [21] \\
\hline Pysiological saline & Brocothirixthermosphacta & 6.05 & 100 & 35 & $5.5(\mathrm{C})$ & \multirow{2}{*}{ Erkmen [21] } \\
\hline Skinned meat & Brocothirixthermosphacta & 6.05 & 150 & 35 & $5(C)$ & \\
\hline MRS broth & L. plantarum & 7 & 100 & 30 & $>8$ & Hong et al. [25] \\
\hline Pysiological saline & Salmonella thyphimurium & 6 & 15 & 35 & $7(\mathrm{C})$ & \multirow{2}{*}{ Erkmen [21] } \\
\hline PS with broth & S. thyphimurium & 6 & 140 & 25 & $7(\mathrm{C})$ & \\
\hline Whole milk & E. coli & 10 & 360 & 30 & $6.42(\mathrm{C})$ & \multirow{2}{*}{ Erkmen [21] } \\
\hline Skim milk & E. coli & 10 & 360 & 30 & $7.24(\mathrm{C})$ & \\
\hline Carrot juice & Aerobic plate count & 4.9 & 10 & 5 & 4 & Park et al. [12] \\
\hline \multicolumn{7}{|c|}{ Treatment in Semi-continuous type DPCD system } \\
\hline Physiological saline & Bacillus subtilis & 7.4 & 2.5 & 38 & $7(\mathrm{C})$ & \multirow{2}{*}{$\begin{array}{c}\text { Spilimbergo et } \\
\text { al. [26] }\end{array}$} \\
\hline & Pseudomonas aeruginosa & 7.4 & 2.5 & 38 & $7(C)$ & \\
\hline \multicolumn{7}{|c|}{ Treatment in Continuous type DPCD system } \\
\hline Sterile water & E. coli & 7.5 & 5.2 & 24 & 8.7 & \multirow{3}{*}{$\begin{array}{l}\text { Sims \& Estigar- } \\
\text { ribia }\end{array}$} \\
\hline \multirow{2}{*}{ Orange juice } & E. coli & 15 & 4.9 & 24 & $>6$ & \\
\hline & Leuconostocmesenteroids & 15 & $<10$ & 25 & $>6$ & \\
\hline
\end{tabular}




\begin{tabular}{|c|c|c|c|c|c|c|}
\hline \multirow{6}{*}{ Apple juice } & S. cerevisiae & 15 & $<10$ & 25 & 12 & \multirow{6}{*}{ Kincal et al. [13] } \\
\hline & L. plantarum & 7.5 & $<10$ & 35 & $>8$ & \\
\hline & S. thyphimurium & 38 & 10 & 25 & 6 & \\
\hline & L. monocytogenes & 38 & 10 & 25 & 6 & \\
\hline & E. coli $0157: \mathrm{H7}$ & 107 & 10 & 25 & 5 & \\
\hline & E. coli0157:H7 & 20.6 & 12 & 25 & 5.7 & \\
\hline Watermelon juice & Aerobic plate count & 34.4 & 5 & 40 & 6.5 & Lecky [27] \\
\hline Mandarin juice & Aerobic plate count & 41.1 & 9 & 35 & 3.47 & Yagizet al. [9] \\
\hline Coconut water & Aerobic plate count & 34.5 & 6 & 25 & $>5$ & $\begin{array}{l}\text { Damar \& Bala- } \\
\text { ban [28] }\end{array}$ \\
\hline
\end{tabular}

$\mathrm{C}=$ complete inactivation .

A summary of inactivation rate achieved of various microorganisms, treatment conditions and type of DPCD systems used is given in Table 1. DPCD can inactivate certain enzymes at temperatures where thermal inactivation is not effective [22]. Enzyme inactivation by DPCD can be due to many causes such as pH lowering, conformational changes of the enzyme, and inhibitory effect of molecular $\mathrm{CO}_{2}$ on enzyme activity. A study on Pectin esterase (PE) inactivation in orange juice is done in DPCD [28]. The $\mathrm{pH}$ of orange juice must be lowered to 2.4 for substantial PE inactivation. DPCD lowers $\mathrm{pH}$ only to 3.1. Therefore, only the $\mathrm{pH}$ lowering effect is not sufficient to explain enzyme inactivation. The results of other researchers also support this conclusion [29].

\section{Applications of DPCD in Food and its Effects on Quality}

Different researchers did many works regarding the applications of DPCD on physiological, biochemical and nutrional quality of foods as well as the inactivation and death kinetics of different micro-organisms.

Some of them are mentioned below:

Cloudy apple juice is treated with supercritical carbon dioxide (SC- $\mathrm{CO}_{2}$ ) and the activity of polyphenol oxidase (PPO), color, and browning degree is investigated at $8,15,22$, and $30 \mathrm{MPa}$ for $60 \mathrm{~min}$ at $55{ }^{\circ} \mathbf{C}$ during storage at $4{ }^{\circ} \mathrm{C}$ for 4 weeks [30]. The PPO activity is substantially reduced with increase in pressure. The total color difference $(\Delta \mathrm{E})$, which is significantly less than that of untreated sample, decreased by enhancing the pressure level. Cloud retention in orange juice is increased between $446 \%$ and $84.6 \%$ with increase in pressure 38 to $108 \mathrm{MPa}$ [21]. Comparison study between effect of supercritical carbon dioxide $\left(\mathrm{SC}-\mathrm{CO}_{2}\right)$ with gaseous $\mathrm{CO}_{2}\left(\mathrm{G}-\mathrm{CO}_{2}\right)$ and liquid $\mathrm{CO}_{2}\left(\mathrm{~L}-\mathrm{CO}_{2}\right)$ shows that endospores of Bacillus subtilis and $B$. stearothermophilus are resistant to $\mathrm{SC}-\mathrm{CO}_{2}$.

Water content has a significant effect on sterilization process $70 \sim 90 \%$ water content leads to better inactivation of Baker's yeast, Escherichia coli, Staphylococcus aureus and conidia of Aspergillus niger at 200 atmospheres and $35{ }^{\circ} \boldsymbol{C}$ whereas water content of 2 $\sim 10 \%$ cannot be sterilized under the same conditions. G- $\mathrm{CO}_{2}$ and L- $\mathrm{CO}_{2}$ has no sterilizing effect against both wet and dry baker's yeast cells, while wet E. coli cells are sterilized with $\mathrm{G}-\mathrm{CO}_{2}$ [24]. Treatment at 100 bar $\mathrm{CO}_{2}$ pressure for $6 \mathrm{~h}$ causes a decrease of 6.42 and $7.24 \log$ cycles of E. coli in whole and skim milk [31]. Increased
$\mathrm{CO}_{2}$ concentrations and temperatures will significantly enhance the bactericidal effect, resulting in a maximum reduction of $7.31 \mathrm{log}$ $\mathrm{cfu} / \mathrm{ml}$ of $E$. coli in apple cider at $8 \% \mathrm{CO}_{2}$ and $42{ }^{\circ} \mathrm{C}$ [23]. Resistance of microorganisms to HPCD treatment changes as a function of treatment time, leading to significant tailing in the survival curves, and is dependent on pressure and temperature.

Transmission electron microscopy shows that HPCD treatment has a profound effect on the intracellular organization of the micro-organisms and influences the permeability of the bacterial cells by introducing pores in the cell wall [17]. Reduction in haze formation along with increase in aroma and flavor retention is found in pasteurization of beer by a continuous dense-phase $\mathrm{CO}_{2}$ system. A maximum log reduction of $7.38 \mathrm{logs}$ in yeast populations is predicted at $26.5 \mathrm{MPa}, 21{ }^{\circ} \mathrm{C}, 9.6 \% \mathrm{CO}_{2}$ and $4.77 \mathrm{~min}$ residence time [32]. Similarly, a reduction of more than a 6-log cycle of yeast population is found in grape juice at the processing condition of 35 ${ }^{\circ} \mathrm{C}$ at a pressure of $48.3 \mathrm{MPa}$ with a $\mathrm{CO}_{2}$ concentration of $170 \mathrm{~g} \mathrm{~kg}^{-1}$ [20]. Suspension medium like fat or oil has adverse effect on the lethality rates of bacteria in DPCD treatment system [33].

It is also showed that an increase in temperature from subcritical to supercritical of carbon dioxide leads to a significant enhancement of rapture rates of yeast cell wall under high pressures, while the functional properties of proteins and the removal of off-flavors are relatively insensitive to the variation of temperature if the process is maintained at or below $35{ }^{\circ} \mathrm{C}$. At higher temperatures, the activities of enzymes begin to decay and are lost at about 55 ${ }^{\circ} \mathrm{C}$. In comparison to conventional treatment, supercritical $\mathrm{CO}_{2}$ has higher lethality rates for Bacillus subtilis spores at a temperature of $60{ }^{\circ} \mathrm{C}$ in $6 \mathrm{~h}$. Use of micro-bubble system plays a significant role for inactivation of microorganisms. Micro-bubble SC- $\mathrm{CO}_{2}$ treatment of B. cereus, B. subtilis, B. megaterium, B. polymyxa, and B. coagulans at $40{ }^{\circ} \mathrm{C}$ and $30 \mathrm{MPa}$ for $30 \mathrm{~min}$ produces greater reduction (about 3 log cycles of reduction) than a similar treatment without a filter and with increase in temperature, the lethality rate gradually increases [34]. HPCD treatment cannot alter the Newtonian flow behavior of the juice, for example, carrot juice, but causes a significant increase in juice viscosity $(\mathrm{P}<0.05)$. The browning degree (BD) and $\mathrm{pH}$ of HPCD-treated carrot juice is decreased but the cloud and titrable acidity (TA) is increased significantly. 


\section{Conclusion}

DPCD is an emerging non-thermal technology among all other technologies of future generations that can inactivate certain microorganisms and enzymes at temperatures low enough to avoid the thermal effects of traditional pasteurization. For that it is also called as 'Cold Pasteurization'. Retention of antioxidants, phytochemicals, organoleptic such as taste, color and appearance by DPCD system will add value to its first successful commercialization. The relatively low process temperatures, the lack of oxygen in the environment, and for some nutrients, the lower $\mathrm{pH}$, protect the vitamins such as vitamin C.DPCD treatment does not only improve food quality, but also promote shelf life and (long-term) safety by inactivating spoilage and pathogenic microorganisms.

\section{References}

1. Daniels JA, Krishnamurti R, Rizvi SSH (1985) A review of effects of $\mathrm{CO}_{2}$ on microbial growth and food quality. Journal of Food Protection 48(6): 532-537.

2. Gunes G, Blum LK, Hotchkiss JH (2005) Inactivation of yeasts in grape juice using a continuous dense phase carbon dioxide processing system. Journal of the Science of Food and Agriculture 85(14): 2362-2368.

3. Jones RP, Greenfield PF (1982) Effect of carbon dioxide on yeast growth and fermentation. Enzyme Microbiology Technology 4(4): 210-223.

4. Meyssami B, Balaban MO, Teixeira AA (1992) Prediction of pH in model systems pressurized with carbon dioxide. Biotechnology Progress 8(2): 149-154.

5. Shimoda M, Cocunubo Castellanos J, Kago H, Miyake M, Osajima Y, et al. (2001) The influence of dissolved $\mathrm{CO}_{2}$ concentration on the death kinetics of Saccharomyces cerevisiae. Journal of Applied Microbiology 91(2): 306-311.

6. Weder JKP, Bokor MV, Hegarty MP (1992) Effect of supercritical $\mathrm{CO}_{2}$ on arginine. Food Chemistry 44(4): 287-290.

7. Parton T, Bertucco A, Elvassore N, Grimolizzi L (2007) A continuous plant for food preservation by high pressure $\mathrm{CO}_{2}$. Journal of Food Engineering 79(4): 1410-1417.

8. Castor TP, Hong GT (1992) Supercritical fluid disruption of and extraction from microbial cells. US Patent 5: 380-826.

9. Yagiz Y, Lim SL, Balaban MO (2005) Continuous high-pressure $\mathrm{CO}_{2}$ processing of mandarin juice: IFT annual meeting book of abstracts, Institute of Food Technologists, New Orleans, Chicago, USA.

10. Yuk GH, Geveke D, Zhang Q (2009) Efficacy of supercritical $\mathrm{CO}_{2}$ for nonthermal inactivation of Escherichia coli- K12 in apple cider International Journal of Food Microbiology 138(1-2): 9199.

11. Kincal D (2000) A continuous high-pressure carbon dioxide system for cloud retention, microbial reduction and quality change in orange juice, M Sci thesis, Gainesville, University of Florida, USA.

12. Park SJ, Lee JI, Park J (2002) Effects of a combined process of highpressure carbon dioxide and high hydrostatic pressure on the quality of carrot juice. Journal of Food Science 67(5): 1827-1834.

13. Kincal D, Hill S, Balaban MO, Marshall MR, Wei C (2005) A continuous high-pressure $\mathrm{CO}_{2}$ system for microbial reduction in orange juice. Journal of Food Science 70(5): 249254.

14. Ishikawa H, Shimoda M, Tamaya K, Yonekura A, Kawano T, et al. (1997) Inactivation of Bacillus spores by the supercritical carbon dioxide microbubble method. Bioscience, Biotechnology, and Biochemistry 61(6): 1022-1023.

15. Ishikawa H, Shimoda M, Kawano T, Osajima Y (1995) Inactivation of enzymes in an aqueous solution by micro-bubbles of supercritical $\mathrm{CO}_{2}$. Bioscience, Biotechnology, and Biochemistry 59(4): 628-631.

16. Wei CI, Balaban MO, Fernando SY, Peplow AJ (1991) Bacterial effect of high pressure $\mathrm{CO}_{2}$ treatment on foods spiked with Listeria or Salmonella. Journal of Food Protection 54(3): 189-193.

17. Enomoto A, Nakamura K, Hakoda M, Amaya N (1997) Lethal effect of high-pressure $\mathrm{CO}_{2}$ on a bacterial spore. Journal of Fermentation and Bioengineering 83(3): 305-307.

18. Arreola AG, Balaban MO, Wei CI, Peplow A, Marshall MR (1991) Effect of supercritical $\mathrm{CO}_{2}$ on microbial populations in single strength orange juice. Journal of Food Quality 14(4): 275-284.

19. Kamihira M, Taniguchi M, Kobayashi T (1987) Sterilization of microorganisms with supercritical carbon dioxide. Agricultural and Biological Chemistry 51(2): 407-412.

20. Haas GJ, Prescott HE, Dudly E, Dick R, Hintlian C, et al. (1989) Inactivation of microorganisms by $\mathrm{CO}_{2}$ under pressure. Journal of Food Safety 9(4): 253-265.

21. Erkmen O (2001) Effects of high-pressure carbon dioxide on Escherichia coli in nutrient broth and milk. International Journal of Food Microbiology 65(1-2): 131-135.

22. Shimoda M, Yamamoto Y, Castellanos J, Tonoike H, Kawano T, et al. (1998) Antimicrobial effects of pressured carbon dioxide in a continuous flow system. Journal of Food Science 63(4): 709-712.

23. Arreola AG, Balaban, MO, Marshall MR, Peplow AJ, Wei CI, et al. (1991) Supercritical $\mathrm{CO}_{2}$ effects on some quality attributes of single strength orange juice. Journal of Food Science 56(4): 1030-1033.

24. Nakamura K, Enomoto A, Fukushima H, Nagai K, Hakoda M (1994) Disruption of microbial cells by the flash discharge of high pressure $\mathrm{CO}_{2}$. Bioscience, Biotechnology, and Biochemistry 58(7): 1297-1301.

25. Hong SI, Pyun YR (1999) Inactivation kinetics of Lactobacillus plantarum by high pressure carbon dioxide. Journal of Food Science 64(4): 728-733.

26. Spilimbergo S, Elvassore N, Bertucco A (2002) Microbial inactivation by high-pressure. Journal of Supercritical Fluids 22(1): 55-63.

27. Lecky M (2005) Shelf life evaluation of watermelon juice after processing with a continuous high-pressure $\mathrm{CO}_{2}$ system. In: IFT annual meeting book of abstracts, Institute of Food Technologists, New Orleans, Chicago, USA.

28. Damar S, Balaban MO (2005) Cold pasteurization of coconut water with a dense phase $\mathrm{CO}_{2}$ system. In: IFT Annual Meeting Book of Abstracts, Institute of Food Technologists, New Orleans, Chicago, USA.

29. Chen JS, Balaban MO, Wei CI, Marshall MR, Hsu WY (1992) Inactivation of polyphenol oxidase by high pressure $\mathrm{CO}_{2}$. Journal of Agriculture and Food Chemistry 40(12): 2345-2349.

30. Fenqi G, Jihong W, Fang C, Xiaojun L, Xiaosong H, et al. (2006) Change of polyphenol oxidase activity, color, and browning degree during storage of cloudy apple juice treated by supercritical carbon dioxide. European Food Research and Technology 223(3): 427-432.

31. Balaban MO, Marshall MR, Wicker L (1995) Inactivation of enzymes in foods with pressurized $\mathrm{CO}_{2}$. US Patent 5: 393-547.

32. Balaban MO (2003) Method and apparatus for continuous flow reduction of microbial and/or enzymatic activity in a liquid beer product using carbon dioxide.

33. Zhou L, Wang Y, Xiaosong Hu, Wu J, Liao X (2009) Effect of high pressure carbon dioxide on the quality of carrot juice. Innovative Food Science and Emerging Technologies 10(3): 321-327.

34. Watanabe T, Furukawa S, Tai T, Hirata J, Narisawa N, et al. (2003) High pressure $\mathrm{CO}_{2}$ decreases the heat tolerance of the bacterial spores. Food Science and Technology Research 9(4): 342-344. 
Creative Commons Attribution 4.0 International License

For possible submissions Click Here

Submit Article
MCDA $\begin{aligned} & \text { Modern Concepts } \\ & \text { s. Developments } \\ & \text { hAs }\end{aligned}$ in Agonomy

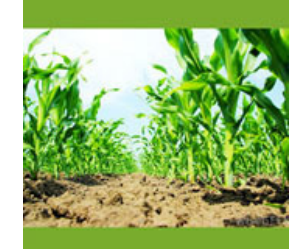

Modern Concepts \& Developments in Agronomy

\section{Benefits of Publishing with us}

- High-level peer review and editorial services

- Freely accessible online immediately upon publication

- Authors retain the copyright to their work

- Licensing it under a Creative Commons license

- Visibility through different online platforms 